\author{
Natalia Możanowicz, Barbara Król, Maja Słupczyńska, \\ Tomasz Hikawczuk, Kamil Sierżant, Martyna Wilk \\ Uniwersytet Przyrodniczy we Wrocławiu \\ e-mail: natalia.mozanowicz@upwr.edu.pl
}

\title{
CECHY METRYCZNE PRZEWODU POKARMOWEGO ORAZ EFEKTY PRODUKCYJNE KURCZĄT RZEŹNYCH ŻYWIONYCH MIESZANKAMI PEŁNOPORCJOWYMI ZAWIERAJĄCYMI DROŻDŻE GORZELNICZE I PIWNE

GROWTH PERFORMANCE AND GASTROINTESTINAL
TRACT ALLOMETRY OF BROILER CHICKENS FED
WITH COMPLETE FEED MIXTURES INCLUDING
DISTILLER'S AND BREWER'S YEAST

DOI: $10.15611 /$ pn.2018.542.09

JEL Classification: Q16

Streszczenie: Celem badań było określenie wpływu drożdży gorzelniczych i piwnych podawanych w mieszankach pełnoporcjowych dla kurcząt rzeźnych na wybrane parametry przewodu pokarmowego oraz efekty produkcyjne. Badania przeprowadzono na 90 kurczętach rzeźnych rasy Hubbard odmiany białej, które w 28. dniu życia przydzielono do 5 grup żywieniowych. Czynnikiem różnicującym grupy żywieniowe był rodzaj i poziom drożdży zastosowanych w mieszance pełnoporcjowej typu finisher. Zwierzęta z grupy kontrolnej otrzymywały mieszankę bez dodatku drożdży, natomiast w grupach doświadczalnych zastosowano 2 i $4 \%$ udziału drożdży gorzelniczych (grupy II i III) oraz 2 i 4\% udziału drożdży piwnych (grupy IV i V). Uzyskane wyniki wskazują, że kurczęta rzeźne otrzymujące w mieszance pełnoporcjowej drożdże, zarówno gorzelnicze, jak i browarniane, charakteryzowały się lepszymi $(\mathrm{P} \leq 0,05)$ wskaźnikami produkcyjnymi: przyrostami masy ciała, pobraniem paszy oraz współczynnikiem wykorzystania paszy na 1 kg przyrostu masy ciała niż ptaki z grupy kontrolnej. Nie stwierdzono istotnego wpływu dodatku drożdży na allometrię przewodu pokarmowego.

Słowa kluczowe: drożdże gorzelnicze, drożdże piwne, brojlery, allometria przewodu pokarmowego, wskaźniki produkcyjne.

Summary: The aim of the study was to determine the effect of distiller's and brewer's yeast added to complete feed mixtures for broiler chickens on selected allometric parameters of digestive tract as well as birds growth performance. The experiment was carried out on 90 Hubbard white broiler chickens randomly divided on $28 \mathrm{~d}$. of the experiment into 5 experimental groups differed by kind and amount of yeasts in complete feed mixtures as follows: group I 
(negative control), groups II and III - distillers yeast in amount of 2 and 4\%, respectively and groups IV and V - brewer's yeast in amount of 2 and 4\%, respectively. Obtained research data indicated that chickens fed with complete feed mixture containing both, brewer's and distillers yeast addition, had higher body weight gains $(\mathrm{P} \leq 0.05)$ in comparison with control group what was clearly confirmed in lower $(\mathrm{P} \leq 0.05)$ FI and FCR. Yeast administration, both distillers and brewers, added to concentrate mixtures did not significantly affect the selected parameters of chicken digestive tract.

Keywords: distiller's yeast, brewer's yeast, broiler, digestive tract allometry, growth performance.

\section{Wstęp}

Wycofanie ze stosowania w żywieniu zwierząt gospodarskich antybiotyków paszowych wpływających na przyspieszenie wzrostu kurcząt doprowadziło do wzrostu zainteresowania innymi dodatkami paszowymi, wpływającymi pozytywnie na zdrowie kurcząt i parametry produkcyjne. Wiele szczepów drożdży jest stosowanych jako źródło białka i niezbędnych aminokwasów w koncentratach dla zwierząt [Steiner 2006]. Drożdże są bogate w białko, którego zawartość wynosi 42-46\%. W porównaniu ze stosowanymi w żywieniu zwierząt produktami ubocznymi soi, białko drożdży jest zasobniejsze w lizynę, jednak zawierają one deficytowe ilości aminokwasów siarkowych. Drożdże zawierają niewielkie ilości tłuszczu surowego, a zawartość węglowodanów wynosi $18-43 \%$. Wartość energetyczna drożdży dla drobiu wynosi 10,3-11,7 MJ/kg. Drożdże stanowią dobre źródło witamin $\mathrm{B}_{2}$ i $\mathrm{B}_{6}$ natomiast są ubogie w witaminy $\mathrm{B}_{1} \mathrm{i}_{12}$. Ponadto są dobrym źródłem składników mineralnych [Çelik i in. 2001] oraz kwasów: foliowego, nikotynowego i pantotenowego oraz niezliczonej ilości związków biologicznie czynnych, m.in. enzymów i L-karnityny. Drożdże zawierają także antybiotyk - malucydynę [Reed, Nagodawithana 1999].

Drożdże, zarówno te gorzelnicze, browarnicze, jak i paszowe, stosowane są w żywieniu zwierząt, a rekomendowany ich dodatek do mieszanek pełnoporcjowych dla drobiu wynosi od 2 do 5\%. Zastosowanie drożdży w poszczególnych fazach wzrostu kurcząt brojlerów wpływa korzystnie na produkcyjność zwierząt. Formujące strukturę ściany komórkowej drożdży oligomannany wpływają pozytywnie na procesy trawienne zachodzące $\mathrm{w}$ przewodzie pokarmowym zwierząt [Dhingra 1993; Saarela i in. 2000]. Dodatkowo drożdże wywierają pozytywny wpływ na system immunologiczny; zapobiegają nadwrażliwości jelit, a w konsekwencji wpływają na lepszą produktywność i zdrowie zwierząt [Steiner 2006].

Zastosowanie drożdży w żywieniu zwierząt jest tematem licznych badań, zarówno w Polsce [Smulikowska i in. 2005; Józefiak i in. 2008; Janocha i in. 2010], jak i za granicą [Stanley i in. 2000; Shashidhara, Devegowda 2003; Al-Mansour i in. 2011]. 
Istnieje jednak niewiele doniesień z zakresu wpływu drożdży podawanych w ostatnim okresie odchowu na cechy allometryczne przewodu pokarmowego ptaków. Stąd też celem podjętych badań było określenie wpływu drożdży gorzelnianych i browarnianych w mieszankach typu finisher dla kurcząt brojlerów w ilości 2 i $4 \%$ na wzrost oraz wybrane cechy metryczne przewodu pokarmowego ptaków.

\section{Material i metody}

Materiał badawczy stanowiło 90 kurcząt brojlerów rasy Hubbard wybranych losowo, z uwzględnieniem średniej masy ciała, spośród grupy 200 sztuk. Zwierzęta do 28. dnia odchowu były żywione standardową mieszanką paszową typu grower (tab. 1).

Tabela 1. Skład i wartość pokarmowa mieszanki treściwej grower

\begin{tabular}{|l|r|}
\hline \multicolumn{1}{|c|}{ Komponenty } & $(\%)$ \\
\hline Śruta kukurydziana & 31,42 \\
Śruta pszenna & 30,00 \\
Olej sojowy & 4,91 \\
Poekstrakcyjna śruta sojowa & 29,83 \\
Fosforan dwuwapniowy & 1,86 \\
Kreda pastewna & 0,29 \\
NaCl & 0,38 \\
Premiks DKA & 1,00 \\
DL-metionina 98\% & 0,22 \\
L-lizyna 98\% & 0,10 \\
\hline \multicolumn{2}{|c|}{ Wartość pokarmowa (na 1 kg mieszanki pełnoporcjowej) } \\
\hline Energia metaboliczna (MJ) & 13,00 \\
Białko surowe (g) & 200,00 \\
Włókno surowe (g) & 40,00 \\
Ca (g) & 9,20 \\
P przyswajalny (g) & 4,00 \\
Na (g) & 1,70 \\
Metionina (g) & 5,02 \\
Lizyna (g) & 11,50 \\
\hline
\end{tabular}

Źródło: opracowanie własne na podstawie badań.

W 28. dniu życia ptaki zostały losowo podzielone na 5 grup eksperymentalnych (18 szt. w każdej grupie - 6 powtórzeń po 3 szt. na każde powtórzenie) i żywione mieszanką pełnoporcjową typu finisher do 42. dnia odchowu. Grupy różniły się między sobą ilością i rodzajem zastosowanych w mieszance drożdży: grupa I - kontrolna - bez dodatku drożdży, grupy II i III: drożdże gorzelnicze w ilości odpowiednio: 2 i $4 \%$ oraz grupy IV i V z drożdżami browarnianymi w ilości odpowiednio: 2 i 4\% (tab. 2). Wszystkie mieszanki były izoenergetyczne i izobiałkowe. Zapewniono wolny dostęp ptaków do wody (poidła kropelkowe) oraz odpowiednie warunki środowiskowe: temperatura w pomieszczeniu między 20 a $25^{\circ} \mathrm{C}$, wilgotność $64-$ 
Tabela 2. Składy i wartości pokarmowe mieszanek treściwych finisher

\begin{tabular}{|c|c|c|c|c|c|}
\hline \multirow[b]{2}{*}{ Komponenty (\%) } & \multicolumn{5}{|c|}{ Grupy żywieniowe } \\
\hline & $\begin{array}{c}\mathrm{I} \\
\mathrm{CON}\end{array}$ & \begin{tabular}{c|} 
II \\
$2 \%$ DY
\end{tabular} & \begin{tabular}{|c|} 
III \\
$4 \%$ DY
\end{tabular} & \begin{tabular}{|c|} 
IV \\
$2 \%$ BY
\end{tabular} & $\begin{array}{c}\mathrm{V} \\
4 \% \mathrm{BY}\end{array}$ \\
\hline Śruta kukurydziana & 29,30 & 28,52 & 33,60 & 29,90 & 33,90 \\
\hline Śruta pszenna & 31,90 & 33,60 & 28,70 & 31,90 & 28,70 \\
\hline Olej sojowy & 5,60 & 5,40 & 5,00 & 5,40 & 5,00 \\
\hline Poekstrakcyjna śruta sojowa & 29,20 & 26,90 & 25,50 & 27,00 & 25,00 \\
\hline Fosforan jednowapniowy & 1,14 & 1,03 & 0,93 & 1,03 & 1,00 \\
\hline Kreda pastewna & 1,30 & 1,10 & 0,90 & 1,37 & 1,25 \\
\hline $\mathrm{NaCl}$ & 0,38 & 0,38 & 0,38 & 0,38 & 0,30 \\
\hline Premiks DKA & 1,00 & 1,00 & 1,00 & 1,00 & 1,00 \\
\hline DL-metionina $98 \%$ & 0,13 & 0,00 & 0,00 & 0,00 & 0,00 \\
\hline L-lizyna 98\% & 0,00 & 0,00 & 0,00 & 0,00 & 0,00 \\
\hline Drożdże gorzelniane & 0,00 & 2,00 & 4,00 & 0,00 & 0,00 \\
\hline Drożdże piwne & 0,00 & 0,00 & 0,00 & 2,00 & 4,00 \\
\hline \multicolumn{6}{|c|}{ Wartość pokarmowa 1 kg mieszanki } \\
\hline Energia metaboliczna (MJ) & 13,21 & 13,24 & 13,21 & 13,23 & 13,24 \\
\hline Białko surowe $(\mathrm{g})$ & 201,10 & 200,40 & 200,90 & 201,20 & 201,30 \\
\hline Włókno surowe $(\mathrm{g})$ & 30,20 & 29,80 & 28,90 & 29,60 & 28,80 \\
\hline $\mathrm{Ca}(\mathrm{g})$ & 8,53 & 8,54 & 8,56 & 8,51 & 8,58 \\
\hline $\mathrm{P}_{\text {przyswajalny }}(\mathrm{g})$ & 3,82 & 3,83 & 3,81 & 3,80 & 3,82 \\
\hline $\mathrm{Na}(\mathrm{g})$ & 1,70 & 1,70 & 1,73 & 1,70 & 1,70 \\
\hline Metionina $(\mathrm{g})$ & 4,31 & 4,22 & 5,45 & 4,49 & 5,970 \\
\hline Lizyna $(\mathrm{g})$ & 9,99 & 15,44 & 21,06 & 10,08 & 25,01 \\
\hline
\end{tabular}

CON - grupa kontrolna, 2\% DY - grupa z 2\% udziału drożdży gorzelnianych w mieszance pełnoporcjowej, 4\% DY - grupa z 4\% udziału drożdży gorzelnianych w mieszance pełnoporcjowej, 2\% BY - grupa z 2\% udziału drożdży piwnych w mieszance pełnoporcjowej, 4\% BY - grupa z 4\% udziału drożdży piwnych w mieszance pełnoporcjowej.

Źródło: opracowanie własne na podstawie badań.

$-70 \%$. Lokalna Komisja Etyczna ds. Eksperymentów na Zwierzętach zaakceptowała wszystkie procedury wykonywane w ramach doświadczenia.

Skład chemiczny mieszanki został określony metodami konwencjonalnymi [AOAC 2000]. Zasobność w azot określono za pomocą aparatu Kjeltec 2300 firmy Foss Tecator, zawartość białka ogólnego określono, mnożąc zawartość azotu przez współczynnik 6,25. Zawartość włókna surowego określono metodą Henneberg-Stohmann z użyciem aparatu Fibertec Tecator. Po wcześniejszej mineralizacji próbek paszy na mokro w roztworze kwasu azotowego zawartość wapnia i sodu określono metodą spektrofotometrii absorpcji atomowej z zastosowaniem aparatu AA 240 FS z SIPS 20 (Varian). Zawartość fosforu oznaczono po wcześniejszej mineralizacji próbek na mokro z użyciem kwasów azotowego i nadchlorowego metodą wanadomolibdenianu amonu. Skład aminokwasowy, po hydrolizie w 6M kwasie solnym, oznaczono za pomocą analizatora aminokwasów (AAA Ingos 400). 
Podczas trwania eksperymentu rejestrowano ilość pobieranej przez kurczęta mieszanki pełnoporcjowej oraz masę ciała ptaków. Uzyskane wyniki posłużyły do określenia zużycia paszy na kilogram przyrostu masy ciała zwierzęcia. Po zakończeniu doświadczenia wszystkie zwierzęta zostały zważone i z każdej grupy wybrano 12 ptaków, z uwzględnieniem średniej masy ciała dla grupy. Ptaki poddano dekapitacji i przeprowadzono dysekcję. Podczas dysekcji określono masę żołądka, wątroby oraz śledziony, a także zmierzono długość poszczególnych odcinków jelita cienkiego (dwunastnicę, jelito czcze i kręte) oraz grubego (w tym jelita ślepego). Uzyskane dane opracowano statystycznie za pomocą dwukierunkowej analizy wariancji z wydzieloną grupą kontrolną (ANOVA) przy użyciu programu Statistica 9.2.

\section{Wyniki i dyskusja}

Istnieje wiele prac dotyczących wpływu zastosowanego rodzaju drożdży na stymulację układu immunologicznego, wsparcie procesu trawienia, rozwój przewodu pokarmowego i równowagę enzymatyczną w jelicie [Liu i in. 2018a; Liu i in. 2018b; Daneshamand i in. 2017a; Daneshamand i in. 2017b]. Zaledwie kilka publikacji dotyczy wpływu drożdży na masę ciała oraz organów przewodu pokarmowego [Seifi i in. 2018; Kermanshahi i in. 2017]. W badaniach wykazano, że zastosowanie dodatku drożdży gorzelniczych bądź browarnianych w żywieniu kurcząt brojlerów między 28. a 42. tygodniem życia nie wpływa na masę organów, z wyjątkiem wątroby (tab. 3), przeliczoną na $100 \mathrm{~g}$ metabolicznej masy ciała (MBW). Masa wątroby ptaków otrzymujących dodatek drożdży w mieszance była wyraźnie niższa $(\mathrm{P} \leq 0,01)$ niż kurcząt z grupy kontrolnej i wynosiła odpowiednio 23,47 i 22,86 g $100 \mathrm{~g}^{-1}$ MBW wobec 25,08 g $100 \mathrm{~g}^{-1}$ MBW. Nie odnotowano wpływu ilości zastosowanych drożdży na masę wątroby ptaków. Masa żołądka mięśniowego, w zależności od rodzaju drożdży, kształtowała się od 18,88 do $19,66 \mathrm{~g} \cdot 100 \mathrm{~g}^{-1} \mathrm{MBW}$, a śledziony między 1,07 a $1,11 \mathrm{~g} \cdot 100 \mathrm{~g}^{-1} \mathrm{MBW}$ (tab. 4). Uzyskane w badaniach własnych wyniki sugerują, że zastosowanie drożdży powoduje obniżenie masy wątroby, żołądka i śledziony. Wynik taki może być rezultatem zbyt krótkiego okresu podawania drożdży w mieszance. Natomiast Farhoomand i Dadvend [2007], podając kurczętom brojlerom drożdże piekarnicze (Saccharomyces cerevisiae) w ilości 5\% mieszanki pełnoporcjowej, wykazali zwiększenie masy wątroby i śledziony. Podobnie Morales-Lopez $i$ in. [2009] odnotowali istotne zwiększenie masy wątroby kurcząt brojlerów po zastosowaniu dodatku ściany komórkowej drożdży bogatych w MOS i glukany (YCW) do mieszanki pełnoporcjowej. Według Awada i in. [2009] oraz Bozkurta i in. [2009] dodatek pro- i prebiotyków powoduje wzrost masy najważniejszych organów układu pokarmowego: wątroby i trzustki, a także kątnicy.

Zastosowanie w odchowie kurcząt brojlerów dodatku drożdży nie wywiera istotnego wpływu na allometrię układu pokarmowego. Zarówno rodzaj drożdży, jak i ich ilość w mieszance nie wpłynęły na długość dwunastnicy, jelita czczego, jelita krętego czy jelita grubego (tab. 5). Najdłuższą dwunastnicę $\left(16,38 \mathrm{~cm} \cdot 100^{-1} \mathrm{~g} \mathrm{MBW}\right)$ 
Tabela 3. Wyniki produkcyjne kurcząt rzeźnych

\begin{tabular}{|c|c|c|c|c|c|}
\hline Wyszczególnienie & $\begin{array}{l}\text { Masa ciała } \\
\text { w 28. dniu } \\
\text { życia (g) }\end{array}$ & $\begin{array}{l}\text { Masa ciała } \\
\text { w 42. dniu } \\
\text { życia (g) }\end{array}$ & $\begin{array}{c}\text { Przyrost } \\
\text { masy ciała }(\mathrm{g})\end{array}$ & $\begin{array}{l}\text { Pobranie } \\
\text { paszy }(\mathrm{g})\end{array}$ & $\begin{array}{c}\text { Zużycie paszy } \\
\text { na } 1 \mathrm{~kg} \\
\text { przyrostu masy } \\
\text { ciała } \\
\left(\mathrm{kg} \cdot \mathrm{kg}^{-1}\right) \\
\end{array}$ \\
\hline $\begin{array}{l}\text { Grupy żywieniowe } \\
\text { I - CON }\end{array}$ & $1102 \pm 112$ & $1936 \pm 281$ & $834 \pm 68^{a}$ & $912 \pm 81^{A}$ & $1,093 \pm 0,183^{\mathrm{A}}$ \\
\hline II $2 \%$ DY & $1086 \pm 142$ & $1954 \pm 237$ & $868 \pm 102^{\mathrm{a}}$ & $756 \pm 53^{\mathrm{B}}$ & $0,871 \pm 0,112^{\mathrm{A}}$ \\
\hline III $4 \%$ DY & $1119 \pm 245$ & $1974 \pm 268$ & $855 \pm 87^{\mathrm{a}}$ & $781 \pm 74^{\mathrm{A}}$ & $0,913 \pm 0,221^{\mathrm{A}}$ \\
\hline IV $2 \% \mathrm{BY}$ & $1049 \pm 233$ & $1946 \pm 288$ & $897 \pm 96^{b}$ & $812 \pm 77^{A}$ & $0,905 \pm 0,143^{\mathrm{A}}$ \\
\hline V 4\% BY & $1079 \pm 248$ & $2027 \pm 244$ & $948 \pm 79^{b}$ & $777 \pm 69^{\mathrm{B}}$ & $0,820 \pm 0,097^{\mathrm{B}}$ \\
\hline Wartość P & 0,4310 & 0,1721 & 0,0247 & 0,0006 & 0,0007 \\
\hline Rodzaj drożdży & & & & & \\
\hline Bez dodatku & $1102 \pm 112$ & $1936 \pm 281$ & $834 \pm 68^{b}$ & $912 \pm 81^{\mathrm{a}}$ & $1,09 \pm 0,183^{\mathrm{a}}$ \\
\hline DY & $1102 \pm 209$ & $1964 \pm 249$ & $862 \pm 94^{b}$ & $768 \pm 66^{b}$ & $0,892 \pm 0,187^{\mathrm{b}}$ \\
\hline BY & $1064 \pm 244$ & $1986 \pm 269$ & $922 \pm 92^{\mathrm{a}}$ & $795 \pm 73^{\mathrm{b}}$ & $0,863 \pm 0,103^{\mathrm{b}}$ \\
\hline Poziom drożdży & & & & & $183^{a}$ \\
\hline $2 \%$ & $1067 \pm 186$ & $\begin{array}{l}1930 \pm 281 \\
1950 \pm 258\end{array}$ & $\begin{array}{l}834 \pm 08^{b} \\
882 \pm 101^{b}\end{array}$ & $\begin{array}{l}912 \pm 81^{\mathrm{a}} \\
784 \pm 69^{\mathrm{b}}\end{array}$ & $\begin{array}{l}1,093 \pm 0,183^{\mathrm{a}} \\
0,888 \pm 0,133^{\mathrm{b}}\end{array}$ \\
\hline $4 \%$ & $1099 \pm 231$ & $2001 \pm 249$ & $901 \pm 82^{b}$ & $779 \pm 73^{b}$ & $0,866 \pm 0,176^{b}$ \\
\hline \multicolumn{6}{|l|}{$\begin{array}{l}\text { Źródło wariancji, } \\
\text { wartość P }\end{array}$} \\
\hline Rodzaj drożdży & 0,5174 & 0,1716 & 0,0265 & 0,0270 & 0,0365 \\
\hline Poziom drożdży & 0,6457 & 0,2333 & 0,0371 & 0,0332 & 0,0433 \\
\hline Rodzaj ×poziom & 0,6301 & 0,2182 & 0,1315 & 0,1204 & 0,0462 \\
\hline
\end{tabular}

a,b Średnie w kolumnach różnią się przy $\mathrm{P} \leq 0,05$. A,B Średnie $\mathrm{w}$ kolumnach różnią się przy $\mathrm{P}<0,01 \mathrm{CON}$ - grupa kontrolna, 2\% DY - grupa z 2\% udziału drożdży gorzelnianych w mieszance pełnoporcjowej, 4\% DY - grupa z 4\% udziału drożdży gorzelnianych w mieszance pełnoporcjowej, $2 \%$ BY - grupa z 2\% udziału drożdży piwnych w mieszance pełnoporcjowej, 4\% BY - grupa z 4\% udziału drożdży piwnych w mieszance pełnoporcjowej.

Źródło: opracowanie własne na podstawie badań.

odnotowano u ptaków otrzymujących w mieszance drożdże browarniane w ilości 2\%; jednocześnie kurczęta, którym zadawano te same drożdże w ilości 4\%, charakteryzowały się najkrótszą dwunastnicą $\left(14,60 \mathrm{~cm} \cdot 100^{-1} \mathrm{~g} \mathrm{MBW}\right)(\mathrm{P} \leq 0,05)$. Długość pozostałych odcinków układu pokarmowego była podobna u ptaków z grup eksperymentalnych i z grupy kontrolnej. Natomiast Farhoomand i Dadvend [2007] stwierdzili w swoich badaniach nad zastosowaniem drożdży piekarniczych (Saccharomyces cerevisiae), że ich 5-procentowy dodatek do mieszanki dla kurcząt brojlerów istotnie $(\mathrm{P}<0,05)$ wpłynął na zmniejszenie długości jelit. Brak jednoznacznych wyników w badaniach własnych dotyczących wpływu dodatku drożdży na cechy metryczne przewodu pokarmowego ptaków może być wynikiem podawania ich tylko w końcowym okresie odchowu. 
Tabela 4. Masa wybranych organów kurcząt brojlerów [g × $100 \mathrm{~g}-1 \mathrm{MBW}]$

\begin{tabular}{|l|c|c|c|}
\hline \multicolumn{1}{|c|}{ Wyszczególnienie } & Wątroba & Żołądek mięśniowy & Śledziona \\
\hline Grupy żywieniowe & & & \\
I - CON & $25,08 \pm 1,77^{\mathrm{A}}$ & $19,66 \pm 2,92$ & $1,11 \pm 0,32$ \\
II 2\% DY & $23,28 \pm 2,07^{\mathrm{B}}$ & $18,67 \pm 2,34$ & $1,06 \pm 0,25$ \\
III 4\% DY & $23,66 \pm 3,94^{\mathrm{B}}$ & $19,15 \pm 1,73$ & $1,09 \pm 0,25$ \\
IV 2\% BY & $23,58 \pm 3,39^{\mathrm{B}}$ & $18,74 \pm 315$ & $1,22 \pm 0,36$ \\
V 4\% BY & $22,14 \pm 3,40^{\mathrm{B}}$ & $19,01 \pm 3,19$ & $1,11 \pm 0,28$ \\
wartość P & 0,6717 & 0,8781 & 0,7525 \\
\hline Rodzaj drożdży & & & \\
Bez dodatku & $25,08 \pm 1,77^{\mathrm{A}}$ & $19,66 \pm 2,92$ & $1,11 \pm 0,32$ \\
DY & $23,47 \pm 3,08^{\mathrm{B}}$ & $18,91 \pm 2,03$ & $1,07 \pm 0,24$ \\
BY & $22,86 \pm 3,40^{\mathrm{B}}$ & $18,88 \pm 3,10$ & $1,16 \pm 0,32$ \\
\hline poziom drożdży & & & \\
0\% & $25,08 \pm 1,77$ & $19,66 \pm 2,92$ & $1,11 \pm 0,32$ \\
2\% & $23,43 \pm 2,75$ & $18,70 \pm 2,71$ & $1,14 \pm 0,31$ \\
4\% & $22,90 \pm 3,68$ & $19,08 \pm 2,51$ & $1,10 \pm 0,26$ \\
\hline Źródło wariancji, wartość P & & & \\
Rodzaj drożdży & 0,0487 & 0,9666 & 0,2744 \\
Poziom drożdży & 0,5436 & 0,6348 & 0,6201 \\
Rodzaj×poziom & 0,0430 & 0,8975 & 0,3858 \\
\hline
\end{tabular}

MBW - metaboliczna masa ciała; A,B Średnie w kolumnach różnią się przy P $\leq 0,01$. CON grupa kontrolna, $2 \%$ DY - grupa z 2\% udziału drożdży gorzelnianych w mieszance pełnoporcjowej, 4\% DY - grupa z 4\% udziału drożdży gorzelnianych w mieszance pełnoporcjowej, 2\% BY - grupa z 2\% udziału drożdży piwnych w mieszance pełnoporcjowej, 4\% BY - grupa z 4\% udziału drożdży piwnych w mieszance pełnoporcjowej.

Źródło: opracowanie własne na podstawie badań.

Wyniki przedstawione w tab. 5 wskazują, że zastosowanie dodatku drożdży do mieszanki pełnoporcjowej dla brojlerów miało pozytywny wpływ na poszczególne parametry produkcyjne ptaków - przyrost masy ciała, pobranie paszy i współczynnik konwersji paszy. Kurczęta otrzymujące dodatek drożdży gorzelniczych lub browarnianych w ilości zarówno 2 , jak i $4 \%$ charakteryzowały się istotnie wyższymi $(\mathrm{P} \leq 0,05)$ przyrostami masy ciała niż ptaki w grupie kontrolnej. Przyrosty masy ciała ptaków otrzymujących w mieszance 2 i $4 \%$ drożdży browarnianych były istotnie wyższe $(\mathrm{P} \leq 0,05)$ niż kurcząt otrzymujących analogiczne ilości drożdży gorzelniczych. Pobranie paszy przez ptaki otrzymujące w mieszance dodatek drożdży było istotnie niższe $(\mathrm{P} \leq 0,05)$ niż w grupie kontrolnej, ale nie zaobserwowano związku między pobraniem paszy a rodzajem zastosowanych drożdży. Najniższe $(\mathrm{P} \leq 0,01)$ pobranie paszy zanotowano u ptaków pobierających mieszankę zawierającą 2\% drożdży gorzelniczych (756 g) oraz mieszankę zawierającą 4\% drożdży browarnianych $(777 \mathrm{~g})$. Dodatek drożdży, bez względu na ich rodzaj i ilość, poprawił wskaźnik wykorzystania paszy $(\mathrm{P} \leq 0,05)$. Najlepszy wskaźnik wykorzystania paszy odnotowano u kurcząt pobierających w mieszance $4 \%$ drożdży browarnianych $\left(0,820 \mathrm{~kg} \cdot \mathrm{kg}^{-1}\right)$. Uzyskane wyniki są zgodne z rezultatami uzyskanymi przez Onifa- 
Tabela 5. Długość wybranych odcinków przewodu pokarmowego kurcząt brojlerów $[\mathrm{cm} \times 100 \mathrm{~g}-1 \mathrm{MBW}]$

\begin{tabular}{|c|c|c|c|c|c|}
\hline Wyszczególnienie & Dwunastnica & Jelito czcze & $\begin{array}{c}\text { Jelito } \\
\text { biodrowe }\end{array}$ & Jelito ślepe & Jelito grube \\
\hline Grupy żywieniowe & & & & & \\
\hline I - CON & $15,97 \pm 0,96$ & $40,59 \pm 3,84$ & $42,72 \pm 3,66$ & $20,98 \pm 1,95$ & $3,99 \pm 0,60$ \\
\hline II $2 \%$ DY & $15,39 \pm 1,38$ & $39,96 \pm 4,04$ & $40,96 \pm 5,08$ & $19,42 \pm 2,37$ & $3,40 \pm 0,57$ \\
\hline III 4\% DY & $15,87 \pm 1,92$ & $41,09 \pm 3,48$ & $41,25 \pm 5,00$ & $19,87 \pm 2,25$ & $3,52 \pm 0,73$ \\
\hline IV $2 \% \mathrm{BY}$ & $16,38 \pm 2,66^{\mathrm{a}}$ & $41,20 \pm 4,28$ & $42,82 \pm 3,64$ & $20,47 \pm 2,54$ & $3,65 \pm 0,73$ \\
\hline V 4\% BY & $14,60 \pm 1,52^{\mathrm{b}}$ & $39,89 \pm 3,54$ & $40,22 \pm 4,56$ & $19,97 \pm 2,85$ & $3,71 \pm 0,35$ \\
\hline Wartość P & 0,0305 & 0,0983 & 0,0823 & 0,5958 & 0,2625 \\
\hline Rodzaj drożdży & & & & & \\
\hline Bez dodatku & $15,97 \pm 0,96$ & $40,59 \pm 3,84$ & $42,72 \pm 3,66$ & $20,98 \pm 1,95$ & $3,99 \pm 0,60$ \\
\hline DY & $15,63 \pm 1,66$ & $40,53 \pm 3,73$ & $41,11 \pm 4,93$ & $19,64 \pm 2,27$ & $3,46 \pm 0,64$ \\
\hline BY & $15,49 \pm 2,31$ & $40,55 \pm 3,90$ & $41,52 \pm 4,24$ & $20,22 \pm 2,65$ & $3,68 \pm 0,56$ \\
\hline Poziom drożdży & & & & & \\
\hline $0 \%$ & $15,97 \pm 0,96$ & $40,59 \pm 3,84$ & $42,72 \pm 3,66$ & $20,98 \pm 1,95$ & $3,99 \pm 0,60$ \\
\hline $2 \%$ & $15,89 \pm 2,13$ & $40,58 \pm 4,12$ & $41,89 \pm 4,42$ & $19,95 \pm 2,46$ & $3,53 \pm 0,65$ \\
\hline $4 \%$ & $15,24 \pm 1,82$ & $40,49 \pm 3,49$ & $40,74 \pm 4,71$ & $19,92 \pm 2,51$ & $3,61 \pm 0,57$ \\
\hline $\begin{array}{l}\text { Źródło wariancji, } \\
\text { wartość P }\end{array}$ & & & & & \\
\hline Rodzaj drożdży & 0,7897 & 0,9823 & 0,7500 & 0,4121 & 0,0513 \\
\hline Poziom drożdży & 0,2124 & 0,9385 & 0,3721 & 0,9635 & 0,6259 \\
\hline Rodzaj×poziom & 0,0325 & 0,2760 & 0,2637 & 0,4979 & 0,8858 \\
\hline
\end{tabular}

MBW - metaboliczna masa ciała; ${ }^{a, b}$ Średnie w kolumnach różnią się przy $\mathrm{P} \leq 0,05 ; \mathrm{CON}-$ grupa kontrolna, $2 \%$ DY - grupa z 2\% udziału drożdży gorzelnianych w mieszance pełnoporcjowej, $4 \%$ DY - grupa z 4\% udziału drożdży gorzelnianych w mieszance pełnoporcjowej, 2\% BY - grupa z 2\% udziału drożdży piwnych w mieszance pełnoporcjowej, 4\% BY - grupa z 4\% udziału drożdży piwnych w mieszance pełnoporcjowej.

Źródło: opracowanie własne na podstawie badań.

de i Babahmde [1996], którzy dowiedli, że zastosowanie dodatku suchych drożdży w mieszance dla kurcząt brojlerów poprawia ich przyrosty dobowe i pobranie paszy. Kurczęta otrzymujące $3 \mathrm{~g}$ suszonych drożdży w $1 \mathrm{~kg}$ mieszanki pełnoporcjowej w końcowym okresie odchowu osiągały wyższą masę ciała niż kurczęta, których diety nie suplementowano drożdżami, podczas gdy zastosowanie dodatku $6 \mathrm{~g}$ suszonych drożdży w $1 \mathrm{~kg}$ mieszanki pełnoporcjowej obniżyło znacząco wskaźnik wykorzystania paszy [Onifade, Babahmde 1996]. Podobne wyniki dotyczące wpływu zastosowania drożdży w mieszankach dla kurcząt brojlerów na przyrosty masy ciała i wskaźnik wykorzystania paszy uzyskali w swoich badaniach Al-Mansour i wsp. [2011], Shareef i Al-Dabbagh [2009], Gao i wsp. [2008], Nilson i wsp. [2004] czy Churchil i Mohan [2000]. Z drugiej jednak strony, doświadczenia prowadzone przez Farhoomanda i Dadvenda [2007] nie wykazały istotnego wpływu drożdży zastosowanych w ilości 1,0 i 5,0\% w mieszance pełnoporcjowej na przyrost masy kurcząt brojlerów; autorzy ci natomiast zanotowali pozytywny wpływ drożdży 
na wykorzystanie paszy przez zwierzęta. White i wsp. [2002] i Van Heugten i wsp. [2003], badając wpływ drożdży na wyniki produkcyjne kurcząt brojlerów w ostatniej fazie odchowu, odnotowali wzrost pobrania paszy i szybszy wzrost ptaków. Niejednoznaczne efekty dotyczące zastosowania drożdży w żywieniu kurcząt rzeźnych potwierdzają konieczność dalszego prowadzenia badań w tym zakresie.

\section{Podsumowanie}

Dodatek drożdży gorzelniczych i browarnianych do mieszanek pełnoporcjowych dla kurcząt brojlerów w ostatniej fazie odchowu, niezależnie od zastosowanej ilości, korzystnie wpłynął na wyniki produkcyjne ptaków, takie jak przyrosty masy ciała, pobranie paszy i jej wykorzystanie. Dodatek obu rodzajów drożdży, niezależnie od zastosowanego poziomu, spowodował zmniejszenie masy wątroby kurcząt. W przeprowadzonych badaniach nie stwierdzono natomiast jednoznacznego wpływu drożdży na cechy morfometryczne przewodu pokarmowego, co może być efektem zbyt krótkiego okresu ich podawania. Istotne różnice, występujące w parametrach produkcyjnych kurcząt otrzymujących zarówno $2 \%$, jak i 4\% drożdży, wskazują, aby w okresie odchowu zalecać podawanie drożdży w ilości $2 \%$ mieszanki pełnoporcjowej.

\section{Literatura}

Al-Mansour S., Al-Khalf A., Al-Homidan I., Fathi M.M., 2011, Feed efficiency and blood hematology of broiler chicks given a diet supplemented with yeast culture, Intern. J. Poult. Sci., vol. 10(8), s. 603-607.

AOAC International, 2000, AOAC Official Methods of Analysis, AOAC Int., Arlington, VA.

Awad W.A., Ghareeb K., Abdel-Raheem S., Böhm J., 2009, Effects of dietary inclusion of probiotic and synbiotic on growth performance, organ weights, and intestinal histomorphology of broiler chickens, Poultry Sci., no. 88, s. 49-55.

Bozkurt M., Küçükyılmaz K., Çatlı A.U., Çınar M., 2009, The effect of single or combined dietary supplementation of prebiotics, organic acid and probiotics on performance and slaughter char acteristics of broilers, S. Afr. J. Anim. Sci., no. 39, s. 197-200.

Çelik K., Denli M., Ozturkan O., 2001, The effect of Saccharomyces cerevisiae and flavomycin on broiler growth performance, Pak. J. Biol. Sci., no. 4, s. 1415-1417.

Churchil R., Mohan B., 2000, Effect of supplementation of broiler rations with live yeast culture, Cheiron, vol. 29 (1-2), s. 23-27.

Daneshamand A., Kermanshahi H., Danesh Mesgaran M., King A.J., Ibrahim S.A., 2017a, Effects of pyrimidine nucleosides on growth performance, gut morphology, digestive enzymes, serum biochemical indices and immune response in broiler chickens, Livestock Science, vol. 204, s. 1-6.

Daneshamand A., Kermanshahi H., Danesh Mesgaran M., King A.J., Ibrahim S.A., 2017b, Effect of purine nucleosides on growth performance, gut morphology, digestive enzymes, serum profile and immune response in broiler chickens, British Poultry Science, vol. 58, iss. 5, s. 536-543.

Dhingra M.M., 1993, Probiotics in poultry diet, Poult. Adviser, no. 26, s. 43-45. 
Farhoomand P., Dadvend A., 2007, Carcass weight, growth performance and internal organs size of broilers fed graded levels of Saccharomyces cerevisiae supplemented diets, Pak. J. Bio. Sci, vol. 10(11), s. 1870-1874.

Fick K.R., McDowell L.R., Miles P.H., Wilkinson N.S., Funk J.D., Conrad J.H., 1979, Methods of Mineral Analysis for Plant and Animal Tissues, 2nd ed., Univ. of Florida, Gainsville.

Gao J., Zhang H.J., Yu S.H., Wu S.G., Yoon I., Quigley J., Gao Y.P., Qi G.H., 2008, Effects of yeast culture in broiler diets on performance and immunomodulatory functions, Poult. Sci, s. 1377-1384.

Janocha A., Milczarek A., Osek M., Turyk Z., 2010, Efektywność bakterii probiotycznych i prebiotyku w żywieniu kurcząt brojlerów, Acta Sci. Pol., Zootechnica, vol. 9(1), s. 21-30.

Józefiak D., Karczmarek S., Rutkowski A., 2008, A note on the effects of selected prebiotics on the performance and ileal microbiota of broiler chickens, J. Anim. Feed Sci., no. 17, s. 92-397.

Kermanshahi H., Heravi R.M., Attar A., Abbasi Pour A.R., Bayat E., Hossein Zadeh M., Daneshmand A., Ibrahim S.A., 2017, Effects of acidified yeast and whey powder on performance, organ weights, intestinal microflora, and gut morphology of male broilers, Rev. Bras. Cienc. Avic., vol. 19, no. 2.

Liu N., Wang J.Q., Jia S.C., Chen Y.K., Wang J.P., 2018a, Effect of yeast cell wall on the growth performance and gut health of broilers challenged with aflatoxin $B 1$ and necrotic enteritis, Poultry Science, vol. 97, iss. 2, s. 477-484.

Liu N., Wang J.Q., Liu Z., Wang Y., Wang J.P., 2018b, Effect of supplemental yeast cell walls on growth performance, gut mucosal glutathione pathway, proteolytic enzymes and transporters in growing broiler chickens, Journal of Animal Science, vol. 96, iss. 4, s. 1330-1337.

Morales-Lopez R., Auclair E., Garcia F., Esteve-Garcia E., Brufau J., 2009, Use of yeast cell walls; $\beta-1$, 3/1, 6-glucans; and mannoproteins in broiler chicken diets, Poultry Science, no. 88, s. 601-607.

Nilson A., Peralta R., Miazzo D., 2004, Use of brewer's yeast (S. cerevisiae) to replace part of the vitamin mineral premix in finisher broiler diets, XXII Worlds Poultry Congress, Istanbul, Turkey.

Onifade A.A., Babahmde G.M., 1996, Supplemental value of dried yeast in a high-fibre diet for broiler chicks, Animal Feed Science Technology, no. 62, s. 91-96.

Reed G., Nagodawithana T.W., 1999, Yeast Technology, 2nd edn., Van Nostrand Reinhold, New York (cited from Pakistan J. Bio. Sci.).

Saarela M., Morgensen G., Fonden R., Matto J., Mattila-Sandholm T., 2000, Probiotic bacteria: safety, functional and technological properties, Journal of Biotechnology, no. 84(3), s. 197-215.

Seifi S., Khoshbakht R., Sayfari R., Gilani A., 2018, Evaluation of a liquid yeast product on growth performance, anatomical structure and gut microbiota of broiler challenged with suboptimal diet and heat stress, Revue Med. Vet., no. 169, s. 93-102.

Shareef A.M., Al-Dabbagh A.S.A., 2009, Effect of probiotic (Saccharomyces cerevisiae) on performance of broiler chicks, Iraqi Journal of Veterinary Sciences, vol. 23, suppl. I, s. 23-29.

Shashidhara R.G., Devegowda G., 2003, Effect of dietary mannan oligosaccharide on broiler breeder production traits and immunity, Poult. Sci., no. 82, s. 1319-1325.

Smulikowska S., Śliżewska K., Biernasik J., Mieczkowska A., Michałowski P., 2005, The effect of probiotic composed of Lactobacillus and yeasts, and of flavomycin on the performance and faecal microflora of broiler chickens, J. Anim. Feed Sci., no. 14, suppl. 1, s. 483-485.

Stanley V.G., Brown C., Sefton A.E., 2000, Comparative evaluation of a yeast culture, manna oligosaccharide and an antibiotic on performance of turkeys, Poult. Sci., no. 79 (suppl. 1), (abstr.), s. 117.

Steiner T., 2006, Managing Gut Health. Natural Growth Promoters as a Key to Animal Performance, Nottingham University Press, Nottingham, UK.

Van Heugten E., Funderburke D.W., Dorton K.L., 2003, Growth performance, nutrient digestibility, and fecal microflora in weanling pigs fed live yeast, J. Anim. Sci., no. 81, s. 1004-1012.

White L.A., Newman M.C., Cromwell G.L., Lindemann M.D., 2002, Brewers dried yeast as a source of mannan oligosaccharides for weanling pigs, J. Anim. Sci., no. 80, s. 2619-2628. 